„Analecta Cracoviensia” 48 (2016), s. 345-36o

DOI: http://dx.doi.org/10.15633/acr.2031

ks. Piotr Kroczek

Uniwersytet Papieski Jana Pawła II w Krakowie

Paweł Ulman

Uniwersytet Ekonomiczny w Krakowie

\title{
Kanoniczne spojrzenie na statystyczne badanie skuteczności duszpasterskiej: komunia święta
}

Praca duszpasterska duchowieństwa parafialnego jest bardzo ważnym elementem funkcjonowania Kościoła. Jest to bowiem podstawowa zorganizowana forma działalności zbawczej Kościoła, polegająca na przekazywaniu orędzia Ewangelii, co umożliwia włączenie przyszłych wiernych do wspólnoty Kościoła i ich trwanie w niej, w celu osiągniecia pełni zbawienia ${ }^{1}$.

Możliwe jest zmierzenie skuteczności pracy duszpasterskiej duchowieństwa. Kościół jest rzeczywistością złożoną z dwóch pierwiastków - ma charakter bosko-ludzki ( $\left.\mathrm{LG}^{2} 8\right)$. Jednakże element boski nie niweluje ze wspólnoty Kościoła cech charakterystycznych dla każdej innej społeczności ludzkiej³. Patrząc więc na stronę ludzką Kościoła, można badać pracę duszpasterzy i jej wpływ na zachowania religijne wiernych przy pomocy narzędzi znanych

Zob. hasło: Duszpasterstwo, [w:] M. Sitarz, Słownik prawa kanonicznego, Poznań 2003, kol. 44.

2 Sacrosanctum Concilium Oecumenicum Vaticanum II, Constitutio dogmatica Lumen gentium de Ecclesia, 21.11.1964, AAS 57 (1965), s. 5-75; tekst łacińsko-polski: Sobór Watykański II, Konstytucja dogmatyczna Lumen gentium o Kościele, [w:] Sobór Watykański II, Konstytucje, dekrety, deklaracje, Poznań 1986, s. 127-265.

3 Zob. R. Sobański, Kościół - prawo - zbawienie, Katowice 1979, s. 81. 
i wykorzystywanych w naukach społecznych ${ }^{4}$. Tak więc pomiar skuteczność pracy duszpasterskiej jest możliwy, a to daje podstawy do analizy wyników pomiaru i wyciagnięcia wniosków natury empirycznej. Te z kolei mogą być pomocne przy podejmowaniu decyzji przez odpowiedzialnych w diecezjach za duszpasterstwo, czyli biskupów diecezjalnych (kan. $383 \$ 1)^{5}$.

Zasadniczym celem niniejszego artykułu jest próba uchwycenia skuteczności pracy duszpasterskiej w zależności od liczby księży pracujących w parafii, poprzez analizę liczby komunikantów przyjętych przez wiernych. Oczywiście, należy od razy zaznaczyć, iż liczba komunii świętych może być jedynym z wielu wskaźników skuteczności duszpasterskiej. Innymi wskaźnikami, które mogą posłużyć badaniu skuteczności pracy duszpasterskiej, są: liczba odbytych przez wiernych spowiedzi świętych, liczba chrztów, liczba osób przyjmujących bierzmowanie czy liczba zawartych kanoniczych małżeństw. Te wskaźniki nie opisują w kompleksowy sposób funkcjonowania Kościoła i nie oddają w pełni wiarygodnie skuteczności pracy duszpasterzy. Po pierwsze, praktyki religijne są tylko jednym $z$ aspektów religijności, a po drugie, nie można w wyczerpujący sposób opisać statystycznie relacji człowieka z Bogiem. Jak się jednak wydaje, to właśnie liczba przyjętych komunii świętych jest najwłaściwszym wskaźnikiem skuteczności duszpasterskiej. Uzasadnianie tego założenia ma charakter dogmatyczny. Leży w treści katolickiej wiary. Będzie ono przedstawione w dalszej części tego artykułu.

Dla jasności dodać trzeba, że tradycyjnie w badaniach statystycznych dotyczących Kościoła katolickiego bierze się pod uwagę liczbę dominicantes i communiactes. Ten pierwszy termin oznacza osoby uczęszczające na niedzielne msze święte. Za podstawę obliczania tego wskaźnika przyjmuje się liczbę zobowiązanych, do których odnosi się liczbę uczestniczących we mszy świętej w dniu badania. Tym dniem musi być niedziela lub inny dzień świąteczny nakazany. W te bowiem dni wierni są zobowiązani uczestniczyć we mszy świętej (kan. 1247). Gdy chodzi o drugi z wymienionych terminów, oznacza

4 Obecnie od strony socjologicznej przedstawiają wiarę w pryzmacie statystyki praktyk religijnych tacy badacze jak: D. Tułowiecki, Bez Boga, Kościoła i zasad? Studium socjologiczne nad religijnością młodzieży, Kraków 2012, s. 203-242, 277-313 oraz J. Mariański, Praktyki religijne $w$ Polsce $w$ procesie przemian. Studium socjologiczne, Sandomierz 2014. Klasycznym dziełem pozostaje G. Le Bras, Études de sociologie religieuse, vol. 1: Sociologie de la pratique religieuse dans les campagnes françaises, Paris 1955.

Cytowane lub przywołane kanony pochodzą z Codex Iuris Canonici auctoritate Ioannis Pauli PP. II promulgatus z dnia 25 stycznia 1983; tekst lacińsko-polski: Kodeks prawa kanonicznego, przekład zatwierdzony przez Konferencję Episkopatu Polski, Pallottinum 1983. 
on osoby przystępujące do komunii świętej na przedmiotowej mszy świętej. Inaczej mówiąc - wskaźnik communicantes obliczany jest jako liczba wiernych przystępujących do komunii świętej odniesiona do liczby zobowiązanych ${ }^{6}$. W niniejszym artykule nie badano dominicantes i communicantes, lecz stosunek osób przyjmujących komunię do liczbę księży pracujących w duszpasterstwie.

Należy także zauważyć, że zasoby ludzkie duchowieństwa - księża, którymi zarządza biskup diecezjalny, są oni bowiem pod jego władzą (kan. $391 \S 1$, kan. $515 \$ 1)$ - są ograniczone. Tak więc badanie skuteczności pracy duszpasterskiej będzie prowadzić do realizacji pobocznego celu tej artykułu, czyli sformułowania wniosków w formie wskazówek dotyczących tego, jak efektywnie wykorzystać te zasoby, aby jak najlepiej zaspokoić potrzeby duszpasterskie wiernych Kościoła katolickiego.

\section{Źródło danych statystycznych}

Dane statystyczne dotyczące Kościoła katolickiego gromadzone są przez różne podmioty, m.in. przez Gus, Departament Wyznań Religijnych oraz Mniejszości Narodowych i Etnicznych Ministerstwa Administracji i Cyfryzacji, Urzędy Skarbowe, a także przez sam Kościół. Źródłem tych danych, poza Narodowym Spisem Powszechnym, jest zwykle sam Kościół, który bada siebie poprzez wyspecjalizowaną instytucję, jaką jest Instytut Statystyki Kościoła Katolickiego SAC w Warszawie. Na potrzeby tego Instytutu każda diecezja w Polsce przygotowuje zastawienie danych. Ich źródłem z kolei są informacje uzyskiwane z każdej parafii diecezji. Dane z archidiecezji krakowskiej, wykorzystane w tym artykule, za rok 2014 były zbierane w następujących obszarach: liczby księży, liczby mieszkańców i liczby katolików zamieszkujących w danej parafii, liczby udzielonych poszczególnych posług duszpasterskich oraz liczby rozdanych komunii świętych. $\mathrm{Z}$ tych sprawozdań zaczerpnięto dane, które poddano analizie w tym artykule .

Nadmienić należy, że niektóre z tych danych mają raczej orientacyjny (szacunkowy) charakter i wyrażają najlepszą wiedzę proboszcza odpowiedzialnego za ich rzetelne zbieranie. W szczególny sposób odnosi się ta właściwość do liczby mieszkańców danej parafii, która przecież składa się z liczby katolików

\footnotetext{
6 GUs, Wyznania religijne, stowarzyszenia narodowościowe i etniczne w Polsce 2009-2011, Warszawa 2013, s. 37.

7 Dane udostępniła archidiecezja krakowska, za co ks. Piotrowi Majerowi, kanclerzowi kurii, autorzy są bardzo wdzięczni.
} 
i akatolików. Odnośnie do tych drugich proboszcz nie ma możliwości pozyskania pełnej informacji, a jedynie może oszacować ich liczbę.

Natomiast dane dotyczące liczby katolików i liczby udzielonych posług duszpasterskich można uważać za wiarygodne. Są one oparte na informacjach odnotowanych $\mathrm{w}$ księgach parafialnych. Zgodnie bowiem z prawem kanonicznym „W każdej parafii należy prowadzić księgi parafialne, a mianowicie ochrzczonych, małżeństw, zmarłych oraz inne, zgodnie z przepisami Konferencji Episkopatu lub biskupa diecezjalnego. Proboszcz ma czuwać nad tym, by księgi były właściwie spisywane i przechowywane” (kan. $535 \$ 1$ ). To samo dotyczy liczby rozdanych komunii świętych. Nie są one odnotowywane w księgach, których prowadzenie jest obowiązkowe na podstawie prawa powszechnego Kościoła, ale w praktyce takie dane są zbierane. Ich obowiązkowość może wypływać z prawa partykularnego danej diecezji.

Liczba chrztów, osób bierzmowanych czy ślubów zależy przede wszystkim od struktury demograficznej danej parafii, czyli od tego, czy zamieszkują ją ludzie młodzi, czy starsi. W pierwszym przypadku można się spodziewać częstszego udzielania sakramentu chrztu i pierwszej komunii świętej oraz sakramentu bierzmowania. Natomiast w drugim przypadku liczniejsze będą kanoniczne małżeństwa, sakrament namaszczenia chorych i pogrzeb. Chcąc określić natężenie tych zdarzeń, należałoby znać wspomnianą strukturę demograficzną, tak aby odnieść liczbę owych zdarzeń do zasobów demograficznych w danej parafii. Takich danych jednak nie ma. Należy wziąć pod uwagę także fakt, że udzielanie sakramentów danej osobie nie jest przypisane do określonej parafii, przykładowo do tej, na terenie której dana osoba zamieszkuje stale lub tymczasowo (kan. $102 \$ 1$ i 2 ), ewentualnie jest zameldowana (art. 28 ust. 1 ustawy o ewidencji ludności ${ }^{8}$ ). Można podać dla zobrazowania, że zdarza się, iż śluby udzielane są poza parafią własną zarówno narzeczonej, jak i narzeczonego. Podobnie może być - choć jak uczy doświadczenie duszpasterskie, takie zjawisko nie występuje często - z chrztami, sakramentem pierwszej komunii świętej czy pogrzebami.

Z kolei liczba rozdanych komunii świętych może być zaniżona albo zawyżona ze względu na uczestnictwo we mszy świętej osób będących spoza danej parafii. Także takie okazjonalne wydarzenia jak: misje święte, rekolekcje czy też popularne wśród wiernych należących do innych parafii odpusty w sanktuariach, które są jednocześnie parafiami, mogą zakłócać obraz statystyczny. Z tego też względu zdecydowano się pominąć w badaniu kościoły

8 Ustawa z dnia 24 września 2010 r. o ewidencji ludności, Dz.U. z 2015, poz. 388. 
rektoralne czy kaplice przycmentarne, w których również udzielano różnych sakramentów, nierzadko $\mathrm{w}$ dużej liczbie. W związku z powyższym przyjęto (mając na uwadze wszystkie powyższe zastrzeżenia), że podstawą pomiaru skuteczności duszpasterskiej w danej parafii będzie liczba udzielanych komunii świętych, w odniesieniu do liczby katolików zamieszkujących teren danej parafii.

\section{Badane parafie}

Każda diecezja (archidiecezja) powinna być - zgodnie z prawem kanoniczym podzielona na parafie (kan. $374 \$ 1$ ). Parafia jest definiowana jako określona wspólnota wiernych, utworzona na sposób stały w Kościele partykularnym (czyli najczęściej w diecezji ${ }^{9}$ ), nad którą pasterską pieczę, pod władzą biskupa diecezjalnego, powierza się proboszczowi jako jej własnemu pasterzowi (kan. $515 \$ 1$ ). Kilka sąsiednich parafii może być łączonych przez biskupa diecezjalnego w specjalne zespoły; takimi są wikariaty rejonowe, czyli dekanaty. Celem tworzenia dekanatów jest wsparcie dla pasterzowania przez wspólne działanie parafii (kan. $374 \$ 2$ ).

Poniżej zostaną przedstawione podstawowe charakterystyki badanej zbiorowości parafii wchodzących w skład archidiecezji krakowskiej. Do badania wzięto 459 parafii z 45 dekanatów. Średnia liczba mieszkańców to 3502,39 osoby, połowa parafii archidiecezji liczy nie więcej niż 2340 osób (mediana). Minimalna liczba osób zamieszkujących teren parafii to 267, natomiast maksymalna wynosi 25000 osób. Dziesięć procent najmniej licznych parafii nie przekracza 940 osób (decyl 1.), natomiast w 10\% najbardziej licznych liczba osób jest co najmniej równa 7750 (decyl 9.). Współczynnik zmienności wynoszący 104\% wskazuje na wysokie zróżnicowanie parafii ze względu na liczbę mieszkańców, natomiast wskaźnik skośności rozkładu wynoszący 2,81 wskazuje na asymetrię prawostronną tego rozkładu.

W przypadku liczby katolików powyższe charakterystyki rozkładu przedstawiają się następująco: średnia liczba katolików to 3414,22 osoby, mediana 2295 osób, minimalna liczba katolików to 267 osób, a maksymalna 24400 osób.

9 Kan. 368: „Kościoły partykularne, w których istnieje i z których składa się jeden i jedyny Kościół katolicki, to przede wszystkim diecezje, z którymi - jeśli nie stwierdza się czegoś innego są zrównane: prałatura terytorialna i opactwo terytorialne, wikariat apostolski i prefektura apostolska, jak również administratura apostolska erygowana na stałe”. 
Decyl pierwszy wynosi 930 katolików, a decyl dziewiąty 7450 osób. Współczynnik zmienności 102,19\%, a skośność rozkładu 2,77.

Biorąc pod uwagę powyższe wyniki, można obliczyć procent osób uznawanych za katolików w archidiecezji krakowskiej. Wynosi on 97,5\%, co jest mniej więcej zgodne $\mathrm{z}$ wynikami ogólnopolskimi $(95,5 \%)^{10}$, jednak znacząco odbiega od obliczeń dokonanych na danych Gus-u, zgodnie z którymi w Polsce procent osób deklarujących wyznanie katolickie nie przekracza 90\%. Rezultat ten jest wynikiem zaniżonej liczby mieszkańców Polski, która po zsumowaniu danych pozyskanych z poszczególnych parafii jest wyraźnie niższa niż podaje to GUS w ramach kategorii ludności faktycznej lub ludności rezydującej. Można więc przypuszczać, że w diecezji krakowskiej wspomniany powyżej procent też jest niższy niż 97,5 .

\section{Księża pracujący w duszpasterstwie}

W Kościele katolickim wśród wiernych wyróżnia się na mocy ustanowienia Bożego: świętych szafarzy i świeckich (kan. 207 \$1). Już mężczyzna przyjmujący diakonat staje się duchownym (kan. $266 \$ 1$ ). Poza wypadkiem diakonów stałych, których liczba w Polsce jest niewielka (wynosi 18 dla obrządku łacińskiego $^{11}$ ), diakonat jest stopniem do przyjęcia święceń prezbiteratu. Prawo kanoniczne z nakazuje zachowanie sześciomiesięcznego odstępu czasu między diakonatem i prezbiteratem (kan. $1031 \$ 1$ ), lecz zabrania przedłużania tego czasu powyżej roku. Zwyczajną drogą jest to, że prezbiter (ksiądz) po święceniach zostaje posłany przez biskupa diecezjalnego do pracy duszpasterskiej w danej parafii.

Wprawdzie diakon może wykonywać pewne posługi duszpasterskie takie jak: posługa Słowa Bożego, czyli przepowiadanie Słowa Bożego czy nauczanie katechetyczne. Nie należą jednak do tego zbioru takie, kluczowe dla duszpasterstwa zadania jak odprawianie mszy (kan. $900 \$ 1$, kan. 904) i słuchanie spowiedzi (kan. 965). Diakonowi, z tej racji, że nie otrzymał on jeszcze święceń kapłańskich, nie można ważnie nadać urzędu związanego z pełnym duszpasterstwem, do wypełniania którego potrzebne jest wykonywanie władzy święceń (kan. 150). W tych powodów, a także tego, że w 2014 roku średnia liczba diakonów (czyli z lat akademickich 2013/2014 oraz 2014/2015)

${ }^{10}$ GUS, Wyznania religijne..., dz. cyt., s. 36.

${ }^{11}$ Źródło: http://www.diakonat.pl/index.php?Page=StaticActual (3.03.2016). 
w archidiecezji krakowskiej wynosiła 17, w tym opracowaniu diakoni nie zostali wzięci pod uwagę $e^{12}$.

Jeżeli chodzi o liczbę księży zamieszkujących w danej parafii, to starano się uwzględnić jedynie tych, którzy pracują w duszpasterstwie tej parafii. Ze względu na cel niniejszego badania takie podejście wydaje się uzasadnione, chociaż z pewnością jest niedoskonałe poprzez swoje zbytnie uproszczenie. Trudno bowiem ustalić wkład w duszpasterstwo danej parafii księży, którzy w niej zamieszkują, a mają inne obowiązki, takie jak praca na naukowa czy praca w kurii diecezjalnej w sądzie diecezjalnym.

Na podstawie danych można stwierdzić, że średnia liczba księży w duszpasterstwie w parafii to 2,02, mediana wynosi 2, czyli w połowie parafii pracuje nie więcej niż dwóch księży. Minimalnie w parafii jest jeden ksiądz, maksymalnie ośmiu. Współczynnik zmienności wynosi 65,18, a skośność rozkładu 1,67.

\section{Komunie święte}

Jak wskazano we wstępie, liczba przyjętych komunii świętych wydaje się dobrym wskaźnikiem skuteczności pracy duszpasterskiej. Eucharystia w życiu religijnym katolików zajmuje bardzo ważne miejsce, jest bowiem „źródłem i zarazem szczytem całego życia chrześcijańskiego" (LG 11, KKK ${ }^{13} 1324$, KKK 1407). Zgodnie $z$ Katechizmem Kościoła katolickiego „Komunia święta pogłębia nasze zjednoczenie z Chrystusem” (KKK 1391). Bez wątpienia więc zadaniem pracy duszpasterskiej powinna być pomoc wiernym w częstym i regularnym przyjmowaniu tego „najbardziej czcigodnego sakramentu” (kan. 897).

Gdy chodzi o praktykę komunii świętej, to Kościół uczy, że każdy wierny po przyjęciu Najświętszej Eucharystii po raz pierwszy - co nota bene dzieję się po dojściu do „używania rozumu” (usum rationis) (kan. 914) - ma obowiązek przyjmować ją przynajmniej raz w roku (kan. $920 \$ 1)$. Inne prawne i duszpasterskie zalecenia mogące mieć znaczenie dla wyników statystycznych są następujące. Zaleca się wiernym przyjmowanie komunii świętej częściej niż raz w roku. Trzeba pamiętać także, że „Kto przyjął już Najświętszą Eucharystię, może ją ponownie tego samego dnia przyjąć jedynie podczas sprawowania Eucharystii, w której uczestniczy" (kan. 917). Tylko wierny, który nie ma świadomości grzechu ciężkiego, może przystąpić do komunii świętej

${ }_{12}$ Diakonów świeconych w archidiecezji krakowskiej w roku 2013 było 22, w roku 2014 - 15, a w roku 2015 -15; źródło: Wyższe Seminarium Duchowne Archidiecezji Krakowskiej.

${ }_{13}$ Katechizm Kościoła katolickiego, Pallottinum 2002. 
(kan. 916). Prawne ograniczenia w przyjmowaniu komunii świętej, takie jak zakazy przyjmowania komunii przez ekskomunikowanych, podlegających interdyktowi, po wymierzeniu lub deklaracji kary, jak również innych osób trwających z uporem w jawnym grzechu ciężkim (kan. 915), nie mają znaczenia statystycznego.

Ważną informację, również ze względu na przeprowadzane badanie, niosą dane o liczbie rozdanych komunii świętych w ciągu roku. Średnio rozdano 68 259,82 komunii. W połowie parafii rozdano nie więcej niż 48 ooo komunii świętych (mediana). Minimalna ich liczba wyniosła 1900, natomiast maksymalna 400000 . W $10 \%$ parafii rozdano nie więcej niż 20 ooo komunii świętych (decyl 1.), a w innych 10\% parafii rozdano co najmniej 140 ooo komunii świętych (decyl 9.). Współczynnik zmienności wynoszący 90,41\% wskazuje również na duże zróżnicowanie parafii ze względu na liczbę udzielonych komunii świętych, a wskaźnik skośności równy 2,46 pokazuje asymetrię prawostronną rozkładu liczby udzielanych komunii.

W badaniach porównawczych ważne jest operowanie wielkościami względnymi, a nie jedynie absolutnymi. $Z$ tego też względu obliczono dla każdej parafii liczbę mieszkańców przypadających na jednego księdza oraz liczbę rozdanych komunii świętych przypadającą na jednego katolika. Pierwszy wskaźnik ma mówić o potencjalnym obciążeniu księży obowiązkami duszpasterskimi wynikającymi z liczby mieszkańców ich parafii, do których kierują swoją posługę duszpasterską. Drugi wskaźnik natomiast odnosi się do wspomnianej wcześniej skuteczności posługi duszpasterskiej wyrażającej się w pełnym uczestnictwie wiernych we mszy świętej. Tak więc średnia liczba mieszkańców przypadających na jednego księdza w archidiecezji krakowskiej wyniosła 1607,81 osoby. W połowie parafii liczba ta wyniosła nie więcej niż 1497,67 osób. Minimalnie było to 164,33 osoby, natomiast maksymalnie 6500 osób. Dziesięć procent parafii miało nie więcej niż 800 osób przypadających na jednego księdza. Z drugiej strony 10\% parafii charakteryzowało się liczbą nie mniejszą niż 2583,33 osób na jednego księdza. W przypadku tego wskaźnika zmienność okazała się relatywnie niewielka. Współczynnik zmienności wyniósł 48,97\%. Wskaźnik skośności $(1,82)$ pokazuje asymetrię prawostronną rozkładu.

Średnia liczby komunii świętych na jednego katolika wyniosła 24,57, natomiast mediana 20,77. Minimalna liczba rozdanych komunii to 1,08, a maksymalnie rozdano 242,96 komunii na jednego katolika zamieszkałego na terenie parafii. Dziesięć procent parafii charakteryzowało się tym, że rozdano tam nie więcej niż 11,35 komunii na jednego katolika, natomiast $\mathrm{w}$ badanej archidiecezji było również 10\% parafii, w których udzielano co najmniej 40,40 
komunii na katolika w ciągu roku. Współczynnik zmienności wyniósł 76,69\%, co wskazuje na znaczne zróżnicowanie parafii w tym obszarze badania. Skośność rozkładu okazała się relatywnie wysoka $(6,48)$, co pokazuje, że są parafie o relatywnie bardzo wysokiej liczbie udzielanych komunii świętych. W obrazowy sposób zostało to przedstawione na wykresach 1 i 2. Prawostronność rozkładu charakteryzuje się większą częstością obserwowaną dla mniejszych wartości badanej cechy (określonego wskaźnika) i ciągnącym się w prawą stronę ogonem rozkładu. Od strony praktycznej prawostronność wyraża się tym, że najczęściej parafie charakteryzują się mniejszą liczbą mieszkańców na księdza czy rozdanych komunii na katolika, niż wynika to ze średniej wartości tych wskaźników. Aby taka sytuacja zaistniała, muszą znaleźć się parafie, które charakteryzują się nadzwyczajnie dużą liczbą mieszkańca na księdza czy rozdanych komunii świętych na katolika w odniesieniu do typowej sytuacji w badanej zbiorowości parafii.

W celu zbadania zależności między skalą potencjalnej pracy duszpasterskiej wyrażoną liczebnością parafii oraz liczbą mieszkańców przypadającą na jednego księdza a efektami pracy duszpasterskiej (religijnością wiernych w parafii) przedstawiono w tabeli 1 średnią wartość liczby udzielonych komunii świętych na katolika w grupach decylowych wspomnianych wcześniej cech.

Wykres 1. Rozkład liczby mieszkańców przypadających na jednego księdza pracującego w duszpasterstwie w archidiecezji krakowskiej w roku 2014

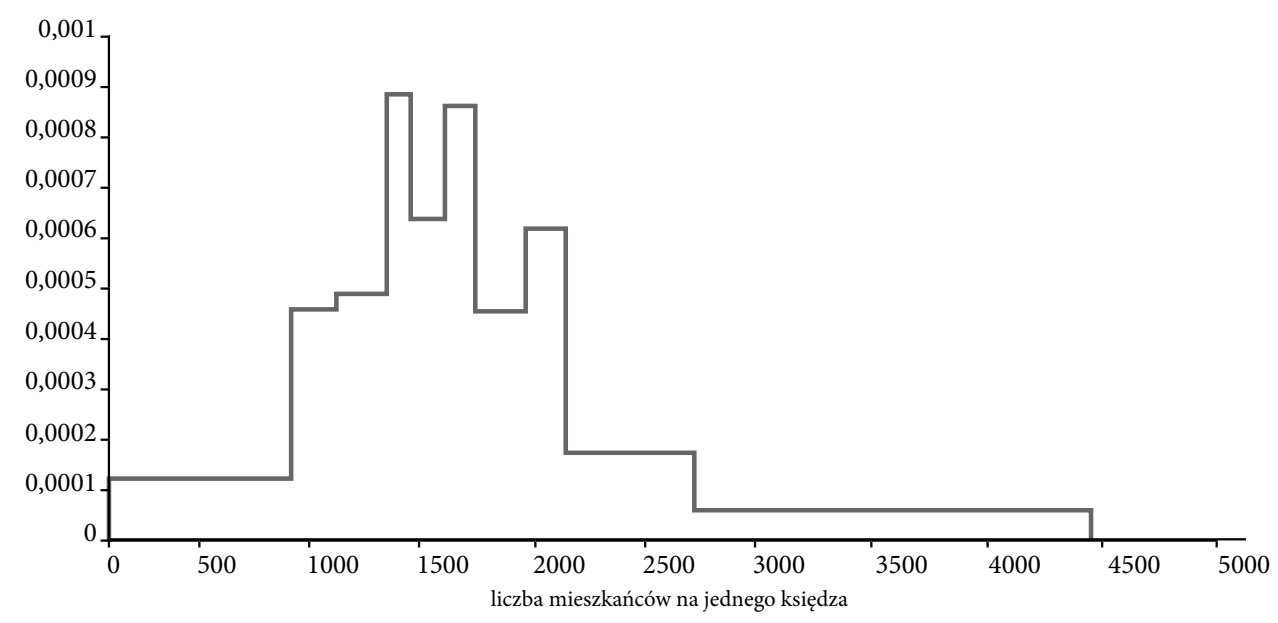

Źródło: opracowanie własne 
Wykres 2. Rozkład liczby rozdanych komunii świętych przypadających na jednego katolika spośród mieszkających w parafiach archidiecezji krakowskiej w roku 2014

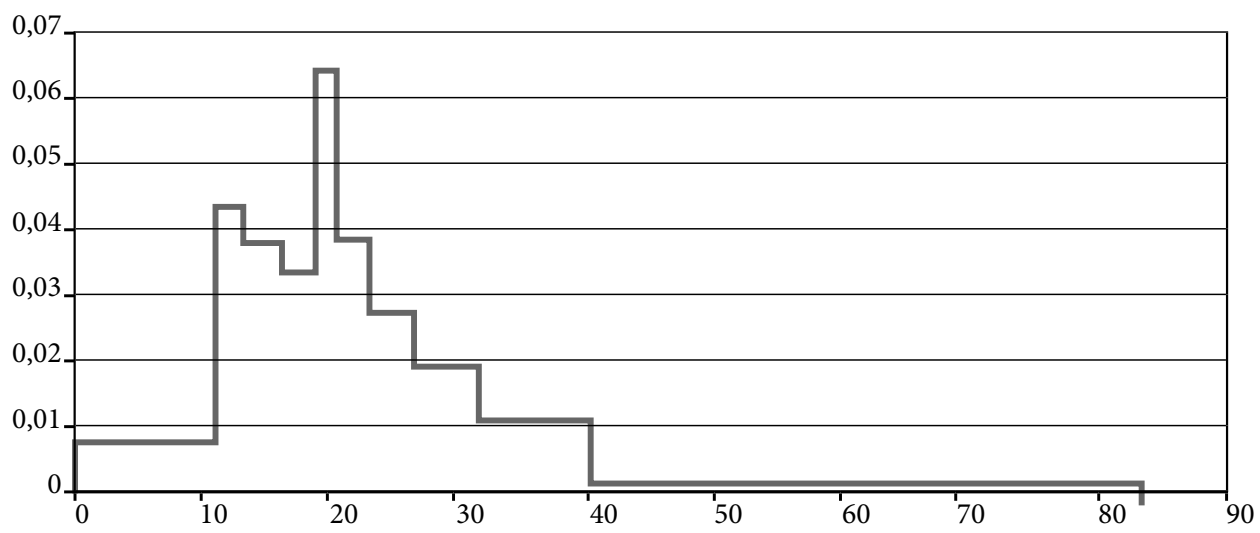

liczba rozdanych komunii na katolika

Źródło: opracowanie własne

Tabela 1. Średnia liczba komunii na katolika w układzie grup decylowych liczby mieszkańców przypadających na księdza oraz liczby mieszkańców w parafii

\begin{tabular}{ccccc}
\hline \multirow{2}{*}{$\begin{array}{c}\text { Grupa } \\
\text { decylowa }\end{array}$} & $\begin{array}{c}\text { W układzie liczby mieszkańców } \\
\text { przypadających na księdza }\end{array}$ & W układzie liczby mieszkańców parafii \\
\cline { 2 - 5 } & $\begin{array}{c}\text { Średnia liczba } \\
\text { komunii na katolika }\end{array}$ & $\begin{array}{c}\text { Liczba obserwacji } \\
\text { a }\end{array}$ & $\begin{array}{c}\text { Średnia liczba } \\
\text { komunii na katolika }\end{array}$ & Liczba obserwacji \\
\hline 1 & 48,18 & 43 & 35,58 & 45 \\
\hline 2 & 28,32 & 47 & 29,11 & 45 \\
\hline 3 & 28,97 & 48 & 29,13 & 42 \\
\hline 4 & 21,99 & 44 & 26,77 & 51 \\
\hline 5 & 23,16 & 48 & 24,75 & 46 \\
\hline 6 & 21,72 & 43 & 19,65 & 46 \\
\hline 7 & 19,23 & 48 & 27,25 & 42 \\
\hline 8 & 22,61 & 37 & 21,42 & 46 \\
\hline 9 & 19,27 & 55 & 17,79 & 46 \\
\hline 10 & 14,20 & 46 & 15,31 & 459 \\
\hline Ogółem & 24,57 & 459 & 24,57 & \\
\hline
\end{tabular}

Źródło: obliczenia własne 
a Właściwością podziału na grupy decylowe jest równa liczebność badanych jednostek w poszczególnych grupach. Jednak w przypadku, gdy wartości badanej cechy powtarzają się (kilka parafii deklaruje taką samą liczbę mieszkańców) i jednocześnie taka sytuacja odnosi się do granicznej wartości, może zaistnieć nierównomierność liczebności poszczególnych grup decylowych.

Można zauważyć wyraźne zmniejszanie się średniej liczby udzielanych komunii świętych na katolika w kolejnych grupach decylowych w obydwu układach. W szczególny sposób jest to widoczne w przypadku grup decylowych odnoszących się do liczby mieszkańców przypadających na jednego księdza pracującego w duszpasterstwie. Wyniki te wskazują, że większe obciążenie księży wiąże się z mniejszą liczbą udzielanych komunii na katolika. Przyznać trzeba jednak, że wniosek ten jest dość ogólny. Wynika on jedynie z porównania poszczególnych parafii ze względu na ich wielkość (liczbę mieszkańców). Nie bierze się pod uwagę innych cech charakteryzujących parafie, tak jak np. położenie parafii (miasto albo wieś) czy struktura demograficzna zamieszkujących tam osób, które mogą mieć wpływ na religijność w danej parafii.

W bardziej dokładny sposób wspomnianą powyżej zależność zobrazowano w tabeli 2. Zestawiono tam liczbę parafii jednocześnie ze względu na grupę decylową liczby mieszkańców przypadających na księdza oraz liczby udzielonych komunii na katolika.

Łatwo zauważyć rozkład wspomnianych liczebności sugerujący zależność religijności w parafii od liczby mieszkańców przypadających na jednego księdza w duszpasterstwie. Dla uproszczenia zestawić można rozkład liczby parafii ze względu na liczbę komunii przypadających na katolika w pierwszej i dziesiątej grupie decylowej liczby mieszkańców przypadających na księdza (pierwszy i dziesiąty wiersz). W pierwszej grupie decylowej (wśród 10\% parafii o najmniejszej liczbie mieszkańców) jedynie jedna jest taka, która zaliczana jest do $10 \%$ parafii o najmniejszej liczbie udzielanych komunii, a 20 - do ostatniej grupy decylowej (10\% parafii o największej liczbie udzielanych komunii na katolika). Odwrotna sytuacja jest obserwowana we wspomnianym dziesiątym wierszu, gdzie najwięcej parafii jest wśród tych, które charakteryzują się niską religijnością katolików.

Syntetycznym potwierdzeniem wspomnianej wyżej zależności są wyniki estymacji prostej regresji zaprezentowane w tabeli 3. Jako zmienną zależną przyjęto logarytm naturalny liczby udzielonych komunii na katolika, natomiast jako zmienną niezależną - logarytm liczby mieszkańców przypadających na księdza. Zlogarytmowanie obydwu wskaźników wiąże się z zastosowaniem potęgowego modelu regresji, który wykorzystuje się w sytuacji, gdy zmienna 
zależna charakteryzuje się rozkładem prawostronnie asymetrycznym. Zastosowanie modelu potęgowego skutkuje z kolei interpretacją ocen parametrów w konwencji elastyczności (zmian wyrażonych w procentach).

Tabela 2. Liczba parafii w układzie grup decylowych dla liczby komunii przypadających na katolika oraz liczby mieszkańców przypadających na księdza

\begin{tabular}{cccccccccccc}
\hline \multirow{2}{*}{$\begin{array}{c}\text { Grupa decylowa } \\
\text { mieszkańców/księdza }\end{array}$} & \multicolumn{8}{c}{ Grupa decylowa liczby komunii przypadajacy na katolika } \\
\cline { 2 - 10 } & 1 & 2 & 3 & 4 & 5 & 6 & 7 & 8 & 9 & 10 & Ogółem \\
\hline 1 & 0 & 3 & 2 & 2 & 7 & 4 & 7 & 8 & 7 & 7 & 47 \\
\hline 3 & 2 & 2 & 2 & 3 & 6 & 3 & 6 & 6 & 11 & 7 & 48 \\
\hline 4 & 6 & 4 & 3 & 7 & 6 & 2 & 5 & 3 & 4 & 4 & 44 \\
\hline 5 & 3 & 5 & 3 & 6 & 3 & 6 & 5 & 8 & 8 & 1 & 48 \\
\hline 6 & 3 & 2 & 9 & 3 & 4 & 6 & 4 & 8 & 3 & 1 & 43 \\
\hline 7 & 3 & 7 & 8 & 7 & 7 & 8 & 3 & 2 & 2 & 1 & 48 \\
\hline 8 & 3 & 3 & 2 & 6 & 5 & 6 & 4 & 2 & 3 & 3 & 37 \\
\hline 9 & 9 & 10 & 6 & 7 & 6 & 5 & 2 & 2 & 6 & 2 & 55 \\
\hline 10 & 15 & 10 & 9 & 5 & 1 & 3 & 1 & 2 & 0 & 0 & 46 \\
\hline Ogółem & 45 & 47 & 45 & 46 & 47 & 46 & 45 & 45 & 47 & 46 & 459 \\
\hline
\end{tabular}

Źródło: obliczenia własne

Tabela 3. Wyniki estymacji parametrów modelu potęgowego dla liczby komunii przypadających na katolika

\begin{tabular}{lllll}
\hline Wyszczególnienie & Ocena parametru & Błąd standardowy & $\mathrm{t}(457)$ & p-value \\
\hline Wyraz wolny & 7,0289 & 0,3340 & 21,05 & $<0,0000$ \\
\hline $\begin{array}{l}\text { Ln liczby mieszkańców } \\
\text { na księdza }\end{array}$ & $-0,5482$ & 0,0458 & $-11,96$ & $<0,0000$
\end{tabular}

Źródło: obliczenia własne 
Obydwa parametry mają statystycznie istotne oceny. Jednak szczególnie istotny jest parametr stojący przy zmiennej niezależnej. Wskazuje on, że jeśli liczba mieszkańców przypadających na jednego księdza wzrośnie o 1\%, to liczba rozdanych komunii na katolika spadnie przeciętnie o blisko 0,55\%. Współczynnik determinacji nie jest wysoki - wynosi o,24, co może wskazywać na odstępstwa od powyższej reguły w przypadku poszczególnych parafii. Ważna jednak jest statystyczna istotność ocen parametrów modelu, wskazująca, że uzyskana relacja nie jest przypadkowa, chociaż nie w pełni wyjaśnia kształtowanie się liczby udzielanych komunii na katolika.

\section{Wnioski i postulaty}

Wnioski z powyższych analiz są następujące.

1. Najwyższa skuteczność pracy duszpasterskiej mierzona liczbą komunii świętych przyjmowanych przez parafian jest przy najniższym obłożeniu wiernych na kapłana. Im większa liczba wiernych na księdza w parafii, tym mniejsza liczba komunii świętych na wiernego.

2. Małe parafie mają większą skuteczność pracy duszpasterskiej. Parafii z ostatniej grupy decylowej ze względu na wielkość (10\% największych parafii - o najwyższej liczbie mieszkańców przypadających na jednego księdza) nie znajduje się wśród 20\% najbardziej skutecznych duszpastersko parafii (dwie ostatnie grupy decylowe ze względu na liczbę komunii świętych).

3. W archidiecezji krakowskiej większość parafii jest mniejsza od średniej wielkości parafii. Wydaje się, że jest to stan prawidłowy. Można jednak postulować, aby ulegał on powiększeniu. Trzeba przy tym postulacie zauważyć, że przy dwóch założeniach: niezmienionej liczbie wiernych w diecezji przypadających na księdza i niezmienionej liczbie parafii, średnia liczba wiernych na księdza (liczona po parafiach) zawsze będzie taka sama. Zmniejszanie jednych parafii musi więc skutkować zwiększaniem innych wspólnot. Innym rozwiązaniem, które umożliwiłoby zmniejszenie liczby wiernych na księdza w parafii, jest zwiększenie liczby parafii, co z kolei musi być związane ze zwiększeniem liczby księży w duszpasterstwie. Jeżeli z powodu spadającej liczby powołań nie da się w przyszłości zmniejszać liczby mieszkańców na księdza, to wówczas należy starać się optymalnie wykorzystywać dla duszpasterstwa zasób księży w archidiecezji. Można po pierwsze spróbować wyznaczyć optymalną dla archidiecezji liczbę mieszkańców na księdza w duszpasterstwie oraz po drugie postulować optymalne wykorzystanie umiejętności danych księży do pracy z różnymi wspólnotami parafialnymi. 
4. Niepokojące jest to, że większość parafii ma skuteczność duszpasterską niższą od średniej. Może to oznaczać, że niewielu kapłanów pracuje wybitnie. Ta obserwacja może także oznaczać, że pomimo dużej liczby księży na parafii ich skuteczność duszpasterska bywa niska. Wniosek, jaki można sformułować, brzmi następująco: należy księży traktować indywidulanie. Na parafie, o których wiadomo, że z racji środowiska parafialnego są trudne duszpastersko, należy posyłać duchownych o większej niż średnia skuteczności duszpasterskiej.

5. Przedstawiony w tabeli 2 rozkład parafii w układzie liczby mieszkańców przypadających na księdza i liczby komunii świętych przypadających na katolika pozwala wyodrębnić grupy parafii różniących się skutecznością duszpasterską w połączeniu z liczbą mieszkańców przypadających na księdza. Ze względu na układ decylowy tabeli w obydwu wymiarach (wierszy i kolumn) liczebność lub udział odpowiednich grup musi się bilansować w tych wymiarach. Przyjmując za kryterium podziału medianę dla każdego ze wspomnianych wymiarów, otrzymujemy cztery grupy parafii: 1 - niska skuteczność i mała liczba mieszkańców przypadających na księdza (udział wynosi 17,4\%); 2 - wysoka skuteczność i mała liczba mieszkańców na księdza (udział wynosi 32,6\%); 3 - niska skuteczność i duża liczba mieszkańców w odniesieniu do jednego księdza (udział wynosi 32,7\%); 4 - wysoka skuteczność i duża liczba mieszkańców na księdza (udział wynosi 17,3\%). Znowu więc znajdujemy potwierdzenie zależności skuteczności duszpasterskiej od poziomu „obciążenia” księdza mieszkańcami parafii. Należy jednak zauważyć, że w powyższym grupowaniu punktem odniesienia dla oceny danej parafii była zbiorowość pozostałych parafii (określano więc miejsce parafii w rankingu ze względu na skuteczność orazliczbę mieszkańców przypadających na księdza). W spomniana ocena ma więc charakter relatywny, a nie obiektywny. Nie ma bowiem absolutnego kryterium odniesienia, czyli modelowego zachowania się parafii. Może się więc okazać, że wszystkie lub większość badanych parafii spełnia jakieś minimalne wymagania skuteczności duszpasterskiej, w tym jedne parafie mają większe, a inne mniejsze osiągnięcia w tym zakresie. $Z$ drugiej strony relatywne podejście pozwala na zastosowanie powyższego podejścia analitycznego do każdej diecezji, niezależnie od religijności diecezjan. Dla pełnego obrazu badanych zjawisk należałoby jednak łącznie wykorzystywać spojrzenie względne i absolutne. Ponadto przy analizie wniosków trzeba również uwzględnić, że dane statystyczne łączą parafie wiejskie i miejskie, a to może zaburzyć powyższą interpretację wyników ze względu na inną liczebność oraz specyfikę życia społeczności wiejskich i miejskich.

Wydaje się, że pasterze archidiecezji krakowskiej intuicyjnie i bazując na doświadczeniu życiowym stosują powyższe zalecenia i wnioski. Jednakże teraz 
zyskali potwierdzenie w postaci naukowego opracowania i interpretacji statystycznych danych.

W podsumowaniu analizy danych trzeba zaznaczyć, że duchowni zasadniczo nie są szkoleni w zbieraniu danych statystycznych. A przecież dane takie mogą posłużyć do analizy duszpasterstwa. Można w tym miejscu sformułować postulat de lege ferenda, aby biskupi diecezjalni, czy to zebrani na Konferencji Episkopatu, czy indywidulanie w diecezjach, wydali zarządzenia, aby w ramach seminariów czy w ramach stałej formacji kapłanów w formie kursu wikariuszowskiego bądź kursu proboszczowskiego przekazać duchownym podstawową wiedzę w tym zakresie.

\section{ABSTRAKT}

Kanoniczne spojrzenie na statystyczne badanie skuteczności duszpasterskiej: komunia święta

Duszpasterstwo jest bardzo ważnym elementem funkcjonowania Kościoła w świecie. Mierzenie skuteczności pracy duszpasterskiej to trudne zadanie, aczkolwiek możliwe do wykonania. Niniejszy artykuł pokazuje, jak tego dokonać, używając narzędzi statystycznych. Jego szczegółowym celem jest pokazanie optymalnego rozłożenia liczby księży na parafię w celu osiągnięcia najwyższej liczby przyjmowanych przez wiernych komunii świętych. Dane do tego badania zostały pozyskane z rzymskokatolickiej archidiecezji krakowskiej i dotyczą 2014 roku. Autorzy wyciągnęli kilka wniosków, które mogą być pomocne biskupowi diecezjalnemu. Dotyczą one rozmieszczenia księży i rozmiaru parafii. Został także sformułowany postulat de lege ferenda, aby lokalne Kościoły stanowiły prawo regulujące gromadzenie danych statystycznych dotyczących życia Kościoła.

\section{SŁOWA KLUCZOWE}

praca duszpasterska, Kościół katolicki, duchowni, komunia święta, archidiecezja krakowska

\section{Abstract}

Canonical view over statistical survey of the effectivness of pastoral work: Holy Communion

Pastoral work is a very important element of the Church functioning in the world. Measuring the effectiveness of pastoral work is a very difficult, but possible task. The article attempts to do that using the statistical tools. The aim is to show the best distri- 
bution of priests for the parishes to achieve the highest number of received Holy communions by the faithful. The data for the survey were taken from the Roman Catholic Archdiocese of Kraków and concern 2014. The authors offer several conclusions which can be of help to the diocesan bishop, regarding the distribution of priests and the size of the parishes. Also one postulate de lege ferenda was formulated that the local churches should have law about collecting statistical data regarding life of the church.

\section{KEYWORDS}

pastoral work, Catholic Church, clergy, Holy Communion, Roman Catholic Archdiocese of Kraków

\section{BIBLIOGRAFIA}

\section{Źródła}

Codex Iuris Canonici auctoritate Ioannis Pauli PP. II promulgatus z dnia 25 stycznia 1983; tekst łacińsko-polski: Kodeks prawa kanonicznego, przekład zatwierdzony przez Konferencję Episkopatu Polski, Pallotinum 1983.

GUS, Wyznania religijne, stowarzyszenia narodowościowe i etniczne w Polsce 2009-2011, Warszawa 2013.

Katechizm Kościoła katolickiego, Pallottinum 2002.

Sacrosanctum Concilium Oecumenicum Vaticanum II, Constitutio dogmatica Lumen gentium de Ecclesia, 21.11.1964, AAS 57 (1965), s. 5-75; tekst łacińsko-polski: Sobór Watykański II, Konstytucja dogmatyczna Lumen gentium o Kościele, [w:] Sobór Watykański II, Konstytucje, dekrety, deklaracje, Poznań 1986, s. 127-265.

Ustawa z dnia 24 września 2010 r. o ewidencji ludności, Dz.U. z 2015, poz. 388.

\section{Literatura}

Le Bras G., Études de sociologie religieuse, vol. 1: Sociologie de la pratique religieuse dans les campagnes françaises, Paris 1955.

Mariański J., Praktyki religijne $w$ Polsce $w$ procesie przemian. Studium socjologiczne, Sandomierz 2014.

Sitarz M., Słownik prawa kanonicznego, Poznań 2003.

Sobański R., Kościót - prawo - zbawienie, Katowice 1979.

Tułowiecki D., Bez Boga, Kościoła i zasad? Studium socjologiczne nad religijnościa młodzieży, Kraków 2012. 